\title{
First report of Chrysodeixis includens (Walker, [1858]) (Lepidotera: Noctuidae) in the dragon fruit (Hylocereus undatus) (Cactaceae)
}

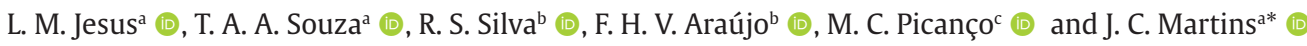 \\ anstituto Federal de Educação, Ciência e Tecnologia Baiano - IF Baiano, Teixeira de Freitas, BA, Brasil \\ ${ }^{\mathrm{b}}$ Universidade Federal dos Vales do Jequitinhonha e Mucuri - UFVJM, Departamento de Agronomia, Diamantina, MG, Brasil \\ c Universidade Federal de Viçosa - UFV, Departamento de Entomologia, Viçosa, MG, Brasil
}

Chrysodeixis includens (Walker) (Lepidoptera: Noctuidae) is one of the most important pests of soy, beans, cotton, sunflower, tobacco, tomatoes, and potatoes (Eichlin and Cunningham, 1978). This species is reported in more than 174 plant species from 39 host families (Specht et al., 2015; CAB International, 2020). The pest is described in the Americas, mainly in southern South America in the northern United States (Moscardi et al., 2012). The egg stage duration for $C$. includens varies between 3 to 5 days, and the larval development is completed in 6 instars (Shour and Sparks, 1981; Barrionuevo et al., 2012; Andrade et al., 2016). C. includens requires almost 30 days to complete its larvae development to the adult when fed on soy or cotton (Shour and Sparks, 1981; Wier and Boethel, 1995; Barrionuevo et al., 2012; Andrade et al., 2016).

Hylocereus undatus (Cactaceae), popularly known as dragon fruit, originates in Mexico and Central and South America (Britton and Rose, 1963; Morton, 1987; Mizrahi et al., 1997). The fruit can be used for fresh human consumption or fruit processing, such as juices or medicinal teas (Liaotrakoon, 2013). This species also has ornamental and medicinal value for presenting attractive flowers and their leaves with healing, diuretic, and hypoglycemic properties (Ibrahim et al., 2018). The cultivation of dragon fruit in Brazil represents a promising and profitable alternative for fruit culture (Silva et al., 2016).

This note aimed to describe the first record of the occurrence of Chrysodeixis includens feeding on Hylocereus undatus, in Brazil.

Immatures of $C$. includens were observed feeding in $H$. undatus' cladodes (variety "Vietnamese White ") during all juvenile stages up to the pupal stage in the experimental area of the Federal Institute of Education, Science and Technology of Bahia, Teixeira de Freitas, Bahia, Brazil ( $17^{\circ} 34^{\prime} 21^{\prime \prime} \mathrm{S}, 39^{\circ} 43^{\prime} 51^{\prime}$ 'W, 68 m altitude), between August 2018 and April 2019. The prevailing regional climate is tropical monsoon and trade wind "Am",based on the Köppen-Geiger classification system, with annual precipitation of $1099 \mathrm{~mm}$, and an average temperature of 24 to $27{ }^{\circ} \mathrm{C}$ (Climate Data, 2020). The pest incidence in the area occurred in the plants' vegetative stage, after 27 days of planting.

Specimens of first and second instar larvae were collected from the plants and sent to the Laboratório de Biologia do Instituto Federal de Educação, Ciência e Tecnologia Baiano, where they were kept and fed of $H$. undatus' cladodes until the emergence of the adults for confirmation of their identity as Chrysodeixis includens Walker, 1858 (Lepidoptera: Noctuidae) by Dr. Júlio Cláudio Martins following identification key (Lafontaine and Poole, 1991; Pogue, 2005).

The larvae collected in the incidence of $C$. includens were green with white longitudinal stripes interspersed with black dots along the body (Figure 1A and 1B). The adult moth had brown to black spots, anterior wings darker than the posterior wings, and silvery-white spots (Figure 1C and 1D). The presence of all immature stages of $C$. includens observed in $H$. untandus suggests that this insect may complete its biological cycle in this host.

In Brazil, C. includens had been reported to feed on plants from various botanical families, such as Asteraceae, Solanaceae, Fabaceae, Lamiaceae, Brassicaceae, Poaceae, Amaranthaceae (Specht et al., 2015). The report of new host plants has been carried out based on sampling carried out in the field and collection of larvae, leading them to adulthood for identification (Ward, 1988). This species had not yet been described as feeding on plants of the Cactaceae family, such as $H$. untandus. Thus, the first report of soybean looper $C$. includens associated with a Cactaceae on H. undatus in Brazil is registering in this communication.

\section{Acknowledgements}

The authors would like to thank the National Council for Scientific and Technological Development (Conselho Nacional de Desenvolvimento Científico e Tecnológico CNPq), the Bahia State Research Foundation (Fundação de Amparo a Pesquisa do Estado da Bahia - FAPESB), the Brazilian Federal Agency for the Support and Evaluation of Graduate Education (Coordenação de Aperfeiçoamento

*e-mail: julioufv@gmail.com

Received: May 25, 2020 - Accepted: November 11, 2020 

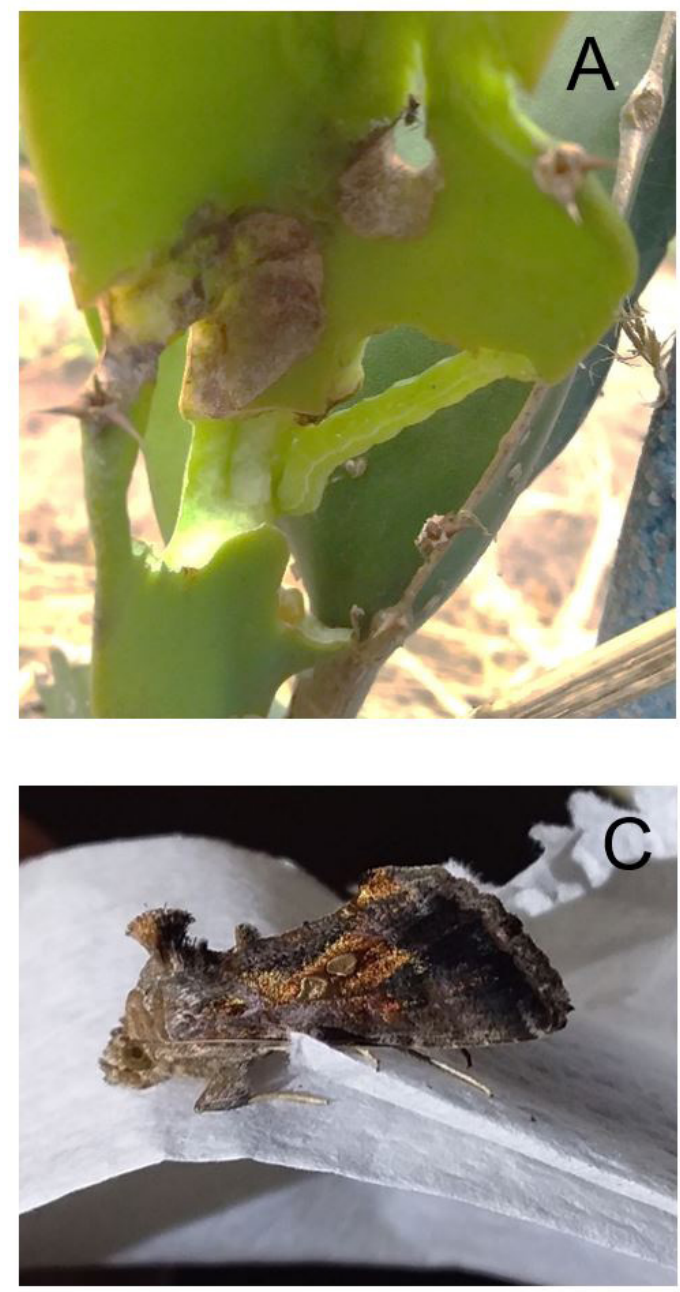
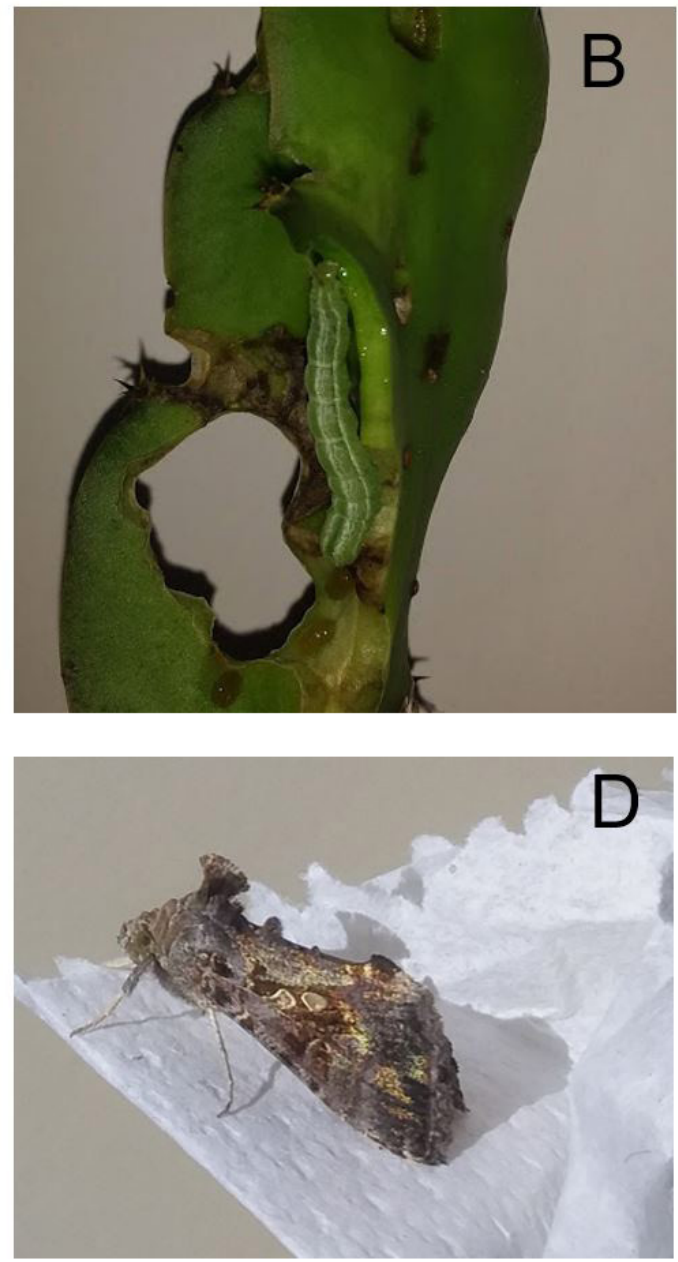

Figure 1. (A and B) Caterpillars on H. undatus; and adults of C. includens (C and D).

de Pessoal de Ensino Superior - CAPES) Finance Code 001, and the Minas Gerais State Foundation for Research Assistance (Fundação de Amparo à Pesquisa do Estado de Minas Gerais - FAPEMIG) for the financial support provided.

\section{References}

ANDRADE, K., BUENO, A.F., SILVA, D.M., STECCA, C.S., PASINI, A. and OLIVEIRA, M.C.N., 2016. Bioecological characteristics of Chrysodeixis includens (Lepidoptera: Noctuidae) fed on different hosts. Austral Entomology, vol. 55, no. 4, pp. 449-454. http:// dx.doi.org/10.1111/aen.12208.

BARRIONUEVO, M.J., MURÚA, M.G., GOANE, L., MEAGHER, R. and NAVARRO, F., 2012. Life table studies of Rachiplusia nu (Guenée) and Chrysodeixis (=Pseudoplusia) includens (Walker) (Lepidoptera: Noctuidae) on artificial diet. The Florida Entomologist, vol. 95, no. 4, pp. 944-951. http://dx.doi.org/10.1653/024.095.0419.

BRITTON, N.L. and ROSE, J.N., 1963. The Cactaceae: description and illustration of plants of the Cactus Family. New York: Carnegie Institution for Science, pp. 183-195. vol. 1.
CAB INTERNATIONAL, 2020 [viewed 15 April 2020]. Crop protection compendium [online]. Available from: http://www. cabicompendium.org/cpc/ home.asp

CLIMATE DATA [online], 2020 [viewed 15 April 2020]. Available from: https://pt.climate-data.org/america-do-sul/brasil/bahia/ teixeira-de-freitas-31961/

EICHLIN, T.D. and CUNNINGHAM, H.B., 1978. The Plusiinae (Lepidoptera: Noctuidae) of America north of Mexico, emphasizing genitalic and larval morphology. Washington: U. S. Department of Agriculture. Tech. Bull., no. 1567.

IBRAHIM, S.R.M., MOHAMED, G.A., KHEDR, A.I.M., ZAYED, M.F. and EL-KHOLY, A.A.E.S., 2018. Genus Hylocereus: beneficial phytochemicals, nutritional importance, and biological relevance: a review. Journal of Food Biochemistry, vol. 42, no. 2, pp. e12491. http://dx.doi.org/10.1111/jfbc.12491.

LAFONTAINE, J.D. and POOLE, R.W., 1991. Noctuoidea, Noctuidae part): Plusiinae. In: R.W. HODGES, D.R. DAVIS, T. DOMINICK, D.C. FERGUSON, J.G. FRANCLEMONT, E.G. MUNROE and J.A. POWELL, eds. The moths of America North of Mexico, fasc. 25.1. Lawrence: Allen Press, 182 p.

LIAOTRAKOON, W., 2013. Characterization of dragon fruit (Hylocereus spp.) components with valorization potential. Ghent: Faculty of Bioscience Engineering, Ghent University. 
MIZRAHI, Y., NERD, A. and NOBEL, P.S., 1997. Cacti as crops. Horticultural Reviews, vol. 18, pp. 291-320.

MORTON, J., 1987. Cactaceae: strawberry pear and related species. In: J.F. MORTON, ed. Fruits of warm climates. Miami, pp. 347-348.

MOSCARDI, F., BUENO, A.F., SOSA-GÓMEZ, D.R., ROGGIA, S., HOFFMAN-CAMPO, C.B., POMARI, A.F., CORSO, I.V. and YANO, S.A.C., 2012. Artrópodes que atacam as folhas da soja. In: C.B. HOFFMANCAMPO, B.S. CORRÊA-FERREIRA and F. MOSCARDI, eds. Soja: manejo integrado de insetos e outros artrópodes-praga. Brasília: Embrapa, pp. 213-309.

POGUE, M.G., 2005. The Plusiinae Lepidoptera: Noctuidae) of Great Smoky Mountains National Park. Zootaxa, vol. 1032, no. 1, pp. 1-28. http://dx.doi.org/10.11646/zootaxa.1032.1.1.

SHOUR, M.H. and SPARKS, T.C., 1981. Biology of the Soybean Looper, Pseudoplusia includens: characterization of Last-Stage Larvae.
Annals of the Entomological Society of America, vol. 74, no. 6, pp. 531-535. http://dx.doi.org/10.1093/aesa/74.6.531.

SILVA, M.J.S., LISBÔA, J.F., LEITE, D.D.F., SILVA, V.M. and FIGUEIRÊDO, R.M.F., 2016. Pitaya: cactácea com características exóticas. In: Anais do Congresso Nacional de Pesquisa e Ensino em Ciências, 2016, Campina Grande. Campina Grande: CONASPEC, vol. 1.

SPECHT, A., DE PAULA-MORAES, S.V. and SOSA-GÓMEZ, D.R., 2015. Host plants of Chrysodeixis includens (Walker) (Lepidoptera, Noctuidae, Plusiinae). Revista Brasileira de Entomologia, vol. 59, no. 4, pp. 343-345. http://dx.doi.org/10.1016/j.rbe.2015.09.002.

WARD, L.K., 1988. The validity and interpretation of insect foodplant records. British Journal of Entomology and Natural History, vol. 1, pp. 153-162.

WIER, A.T. and BOETHEL, D.J. 1995. Foliage consumption and larval development of three noctuid pests on soybean and cotton. Journal of Entomological Science, vol. 30, no. 3, pp. 359-361. http://dx.doi.org/10.18474/0749-8004-30.3.359. 